\title{
UTILIZATION OF APPLE POMACE AS SUBSTRATE FOR PECTINOLYTIC MICROORGANISMS FOR THE PRODUCTION OF AROMATIC FRUITY COMPOUNDS
}

\section{UTILIZAÇÃO DO RESÍDUO DE MAÇÃ COMO SUBSTRATO PARA MICRO-ORGANISMOS PECTINOLÍTIÇOS VISANDO À PRODUÇÃO DE COMPOSTOS AROMÁTICOS FRUTAIS}

\author{
Alisson Reis Canto ${ }^{1}$; Carlos Antonio Gallo Junior ${ }^{2}$; Maria Angélica Vívan ${ }^{3}$ \\ ${ }^{1,2,3}$ Universidade Estadual de Campinas - UNICAMP - Campinas - Brasil alissondosreis@ibest.com.br
}

\begin{abstract}
It is known that the apple pomace is a product without economic value, it contains considerable content of fiber and soluble solids, corresponding mainly of glucose, fructose and sucrose. With this composition, the apple pomace becomes a potential substrate for the growth of microorganisms without needing large nutritional supplementation. Thus, the objective of this study was to promote the bioconversion of apple pomace (Malus domestica cv Fuji) using pectinolytic microorganisms aiming the production of aromatic fruity compounds. Four strains (70, 73, 74 and 144) were used and different proportions of apple pomace 5, 10, 20 and $30 \%\left(w v^{-1}\right)$ were tested as substrate to a liquid fermentation for 72 hours. It was observed a yield of $21.1 \pm 2.43 \%$ bagasse and $78.9 \pm 2.43 \%$ juice. The bagasse had large quantities of water $(76.5 \pm 5.39 \%)$. Among the proportions, the most appropriate was $20 \%$, presenting fluidity and production of aroma. All strains grew on the medium and in accordance with sensory analysis only 70 and 74 strains produced fruit aroma that were described as banana flavor. This study is the first report using apple pomace as a potential appliance for the bioconversion aimed at producing fruity aroma without needing large nutritional supplementation.
\end{abstract}

Key-words: Malus domestica, bioconversion; agro-industrial wastes, aroma fruity.

\section{Introduction}

The apple tree (Malus domestica Bokhausen) belongs to the Rosaceae family, which covers more of the 2.000 species, among there are a large group of plants known for their importance in food, such as: cherry (Prunus avium), plum (P. domestica) and peach (P. persica) (PETRI and LEITE, 2008). According to data from the Food and Agriculture Organization (FAO, 2010), Brazil is the $9^{\text {th }}$ producer of apple with an annual production of approximately 1.27 millions of tons, being the largest in South America.

Among the various ways of use and consumption of apple, about $80 \%$ of national production is destined for in natura consumption, and those which present no quality to be classified in natura are designated to be processed by food industry (MELLO, 2005). Among the manufactured products, the concentrate juice is the major, but its extraction process results in solid 
waste (bagasse) composed of: peel and pulp (94.5\%); seeds (4.4\%) and centers (1.1\%) (KENNEDY et al., 1999).

In Brazil, this solid waste has as main destiny the soil, serving as organic fertilizer, or it can be used as animal feed. In this context, the apple processing industry has shown interest in economic and technological viable alternatives to the use of this waste (VILLAS BÔAS and ESPÓSITO, 2000; RAUPP et al., 2000).

Once this residue without economic value contains approximately $11.6 \%$ fiber composed of cellulose, lignin, pectin and hemicelluloses, as well as $14 \%$ soluble solids which the majority correspond to the sugars glucose, fructose and sucrose, this has a potential for growth of microorganisms, being an interesting tool for biotechnological processes, without the need of nutritional supplementations (DOWNING, 1989; CHEN et al., 1988; KENNEDY et al., 1999).

Several studies about biotransformation of apple pomace have been reported in scientific journals, such as production of enzymes, like polygalacturonase for Aspergillus niger (HANG and WOODAMS, 1994); production of lactic acid (GULLÓN et al., 2008); production of xanthan gum (DRUZIAN and PAGLIARINI, 2007), and also fatty acids such as $\gamma$-linolenic acid produced by Thamnidium elegans (STREDANSKI et al., 2000).

According to Chiappini (2007), the first scientific report of selected bacteria and fungi having the ability to produce aroma was in 1923 by Omelianski. However, the relationship between microbial physiology and the production of odorous metabolites only occurred in studies conducted in the past 50 years. After this work, various studies about aroma compounds produced by bacteria, yeasts and molds started to appear at significant levels, as for example, the study published by Carvalho et al. (2012), which evaluated the development of fruity aroma by different strains of Neurospora sp. using green coffee beans to formulate an alternative culture media; Bramoski et al. (1998) evaluated the fruity aroma production by Ceratocystis fimbriata in solid cultures from agroindustrial wastes.

Thus, the objective of this study was to evaluate the potential of bioconversion of apple pomace (M. domestica cv Fuji) by pectinolytic microorganisms for the production of aromatic fruity compounds.

\section{Material and methods}

\section{Material}

The apple pomace was obtained from fruits of the cultivar Fuji acquired in local markets in the city of Campinas-SP, these were processed in centrifuge Juice (Walita-RI1865) and the bagasse used for the substrate preparation. 
The microorganisms used for the screening were isolated from agro-industrial residues in the study of Uenojo and Pastore (2006). They were reported as fruit flavors producers and designated for fermentation tests in media containing pectin. The total of four strains of pectinolytic microorganisms $(70,73,74$ and 144) were used, after the growing in culture media of Potato Dextrose Agar (PDA) at $30{ }^{\circ} \mathrm{C}$ for 72 hours.

\section{Substrate preparation}

For the substrate preparation, proportions of 5, 10, 20 and $30 \%\left(\mathrm{w} \mathrm{v}^{-1}\right)$ of apple pomace were prepared by dilution in distilled water, resulting in $100 \mathrm{~mL}$ of wet bagasse. Then they were sterilized in autoclave at $121{ }^{\circ} \mathrm{C}, 1$ atm for 15 minutes.

\section{Bioconversion}

The bioconversion occurred in $250 \mathrm{~mL}$ Erlenmeyer flasks properly sealed. The microorganisms were inoculated transferring a loopful of yeast cells or a fragment of agar $\left(1 \mathrm{~cm}^{2}\right)$ containing mycelium of molds and homogenized in the substrate with the aid of an ultra turrax (IKA - T18 Basic) for 20 seconds. After inoculation, the Erlenmeyer flasks were incubated in a shaker (New Brunswick Scientific - Innova4335) at $30^{\circ} \mathrm{C}, 150 \mathrm{rpm}$ for 72 hours.

\section{Extraction of volatile compounds}

The extraction of volatile compounds occurred after $0,24,48$ and 72 hours of bioconversion using ethyl acetate. This was homogenized with $0.5 \mathrm{~mL}$ of sample in a vortex (Biomixer) for 40 seconds and after centrifugation the supernatant was collected and injected $1 \mu \mathrm{L}$ in the gas chromatograph - GC.

\section{Analytical procedures}

The moisture content of the bagasse was determined by gravimetric method (Method 44-15) described by AACC (1995).

The odor of the cultures was determined only by sensory evaluation using an untrained panel of three judges, being requested the olfactory analysis of cultures in Erlenmeyer flasks describing the aromas perceived and their respective intensities during a session of group discussion, according to the intensity scale described by Uenojo and Pastore (2006).

The volatile compounds produced during the bioconversion were monitored by the appearance of peaks by gas chromatography (Agilent Technologies - 7890A). The separation was

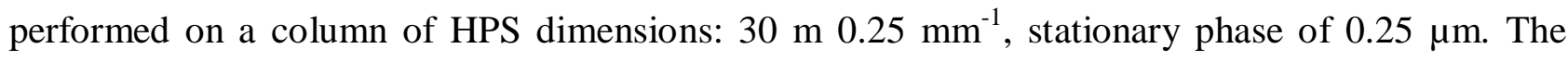


parameters were: gas helium $(\mathrm{He})$, with speed of $1 \mathrm{~mL} \min ^{-1}$; injector temperature: $250{ }^{\circ} \mathrm{C}$ and detector temperature: $250{ }^{\circ} \mathrm{C}$.

All experiments mentioned above were performed in triplicate.

\section{Results and discussion}

It was observed yields of $21.1 \pm 2.4 \%$ of bagasse, which is mostly consisted of water (moisture content), about $76.5 \pm 0.3 \%$. Comparing the results of this study with the mentioned in the literature, it was observed values similar in studies of Downing (1989) and Chen et al. (1988), which reported levels of approximately $80 \%$ moisture.

Once it is known the moisture content of the bagasse used for preparing of the substrate, the solids content of the formulations at 5,10, 20 and 30\% ( $\left.\mathrm{w} \mathrm{v}^{-1}\right)$ were respectively 1.2, 2.7, 5.4 and $8.1 \%$.

In this study the objective was to realize the biotransformation in liquid medium, then different dilutions of apple pomace were tested. The substrates containing 5 and $10 \%\left(\mathrm{w} \mathrm{v}^{-1}\right)$ of bagasse showed fluidity and after 72 hours of incubation it was observed the growth of the microorganism, but it did not present production of aroma. It is supposed that the medium was much diluted, not being sufficient solid to occur bioconversion.

The substrate with $20 \%\left(\mathrm{w} \mathrm{v}^{-1}\right)$ of bagasse showed fluidity and after 72 hours of incubation it was observed the growth of the microorganism and production of fruity aroma.

The medium with $30 \%\left(\mathrm{w} \mathrm{v}^{-1}\right)$ of bagasse did not show fluidity and after 72 hours of incubation it was observed the growth of the microorganism and producing fruity aroma.

Through the results described, it was selected as the best composition to a bioconversion the medium liquid in the proportion of $20 \%$ as it showed fluidity, allowing agitation, besides producing fruity aroma without the need to complement the medium of cultivation with other nutrients.

All strains used in screening showed growth on the substrate and in accordance with the sensory evaluation, conducted by a panel not trained, only the strains 70 and 74 produced pleasant fruit aroma of low intensity, described as banana aromas for both strains. Strains 73 and 144 showed an unpleasant intense aroma of solvent, describe as acetone (Table 1).

Comparing these results with the mentioned in the study of Uenojo and Pastore (2006) that the medium used was fructose and yeast extract, the strain 70 produced fruity aroma (pineapple and pear) and fermented. For strain 74 were described the production of fruity aroma (banana) and the aroma of chocolate. The strain 73 produced fruity aroma (banana, pineapple, raspberry), and the aroma of solvent which also was described for strain 144, agreeing with the data presented in this study. 
Table 1 - Sensory descriptions of the aromas perceived in medium with $20 \%\left(\mathrm{w} \mathrm{v}^{-1}\right)$ of apple pomace

\begin{tabular}{lcc}
\hline Microorganism & Description of aroma & Intensity \\
\hline 70 (mold) & banana & low $(++)$ \\
73 (yeast) & solvent & intense $(++++)$ \\
74 (mold) & banana & low $(++)$ \\
144 (yeast) & solvent & intense $(++++)$ \\
\hline
\end{tabular}

According to reports from Uenojo and Pastore (2006), these strains are indicated for use in biotransformations of culture medium consisting of agro-industrial waste containing pectin. According to these authors the strains were grown in medium containing agro-industrial wastes such as coffee husks, grape pomace, orange and lemon, being able to develop in these medium and to produce fruity flavors. However, using apple pomace, this study is the first report.

Table 2 presents the retention time and the peak area in percentage of the substances detected in chromatographic runs.

Table 2 - Retention time (minutes) and peak area (\%) of the substances detected in chromatographic runs

\begin{tabular}{|c|c|c|c|c|c|c|c|c|c|c|}
\hline \multirow{2}{*}{ Peak } & \multicolumn{5}{|c|}{ Retention time (min) } & \multicolumn{5}{|c|}{$\operatorname{area}(\%)$} \\
\hline & Control & $\mathbf{0 h}$ & $24 h$ & $48 h$ & $72 \mathrm{~h}$ & Control & $\mathbf{0 h}$ & $24 h$ & $48 h$ & $72 \mathrm{~h}$ \\
\hline 1 & 1.23 & 1.24 & 1.23 & nd & 1.23 & 0.011 & 2.080 & 0.01 & nd & 0.02 \\
\hline 2 & 1.30 & nd & 1.29 & 1.29 & nd & 2.080 & nd & 3.28 & 3.15 & nd \\
\hline 3 & 1.41 & 1.40 & 1.40 & 1.40 & 1.40 & 96.02 & 95.93 & 94.59 & 94.98 & 98.01 \\
\hline 4 & 1.54 & 1.54 & nd & 1.54 & 1.54 & 0.001 & 0.001 & nd & 0.001 & 0.0007 \\
\hline 5 & nd & nd & nd & nd & 1.56 & nd & nd & nd & nd & 0.001 \\
\hline 6 & 1.59 & 1.59 & 1.59 & 1.59 & 1.59 & 0.063 & 0.063 & 0.061 & 0.065 & 0.063 \\
\hline 7 & 1.63 & 1.63 & 1.63 & 1.63 & 1.63 & 0.002 & 0.003 & 0.003 & 0.003 & 0.003 \\
\hline 8 & 1.70 & nd & nd & 1.70 & 1.70 & 0.0002 & nd & nd & 0.0005 & 0.0004 \\
\hline 9 & 1.76 & 1.76 & 1.76 & 1.76 & 1.76 & 0.004 & 0.004 & 0.004 & 0.004 & 0.004 \\
\hline 10 & 1.85 & 1.85 & 1.85 & 1.85 & 1.85 & 0.003 & 0.008 & 0.003 & 0.003 & 0.003 \\
\hline 11 & 1.91 & 1.92 & 1.89 & 1.89 & nd & 0.003 & 0.0001 & 0.008 & 0.007 & nd \\
\hline 12 & 1.97 & 1.97 & 1.97 & 1.97 & 1.97 & 0.25 & 0.25 & 0.24 & 0.26 & 0.26 \\
\hline 13 & 2.05 & 2.05 & 2.05 & 2.05 & 2.05 & 0.003 & 0.003 & 0.003 & 0.003 & 0.003 \\
\hline
\end{tabular}


Continuation Table 2 - Retention time (minutes) and peak area (\%) of the substances detected in chromatographic runs

\begin{tabular}{|c|c|c|c|c|c|c|c|c|c|c|}
\hline 14 & 2.28 & 2.28 & 2.28 & 2.28 & 2.28 & 0.0003 & 0.0003 & 0.0003 & 0.0003 & 0.0003 \\
\hline 15 & nd & nd & nd & nd & 2.32 & nd & nd & nd & nd & 0.0002 \\
\hline 16 & 2.34 & 2.34 & 2.34 & 2.34 & 2.34 & 0.0008 & 0.0008 & 0.0008 & 0.0008 & 0.0005 \\
\hline 17 & 2.56 & 2.56 & nd & 2.56 & 2.56 & 0.0002 & 0.0002 & nd & 0.0002 & 0.0002 \\
\hline 18 & 2.86 & 2.86 & 2.86 & 2.86 & 2.86 & 0.0002 & 0.0002 & 0.0002 & 0.0002 & 0.0002 \\
\hline 19 & 3.60 & 3.60 & 3.60 & 3.60 & 3.60 & 0.0008 & 0.0008 & 0.0009 & 0.0008 & 0.0009 \\
\hline 20 & 3.75 & 3.75 & 3.75 & 3.75 & 3.75 & 0.005 & 0.005 & 0.006 & 0.005 & 0.005 \\
\hline 21 & 4.08 & 4.04 & 4.07 & 4.07 & nd & 0.038 & 0.043 & 0.066 & 0.063 & nd \\
\hline 22 & 4.19 & 4.19 & 4.18 & 4.18 & 4.19 & 1.49 & 1.58 & 1.69 & 1.42 & 1.61 \\
\hline 23 & 4.33 & 4.33 & 4.33 & 4.33 & 4.33 & $<0.0001$ & $<0.0001$ & $<0.0001$ & $<0.0001$ & $<0.0001$ \\
\hline 24 & 4.60 & 4.60 & 4.60 & 4.60 & 4.60 & 0.0003 & 0.0003 & 0.0003 & 0.0003 & 0.0003 \\
\hline 25 & 4.81 & 4.81 & 4.81 & 4.81 & 4.81 & $<0.0001$ & $<0.0001$ & $<0.0001$ & $<0.0001$ & $<0.0001$ \\
\hline 26 & 5.29 & 5.29 & 5.29 & 5.29 & 5.29 & 0.002 & 0.002 & 0.002 & 0.002 & 0.002 \\
\hline 27 & 5.87 & 5.87 & nd & nd & 5.87 & 0.0001 & 0.0001 & nd & nd & 0.0001 \\
\hline 28 & 6.29 & 6.29 & 6.29 & 6.29 & 6.29 & 0.0007 & 0.0007 & 0.0008 & 0.0007 & 0.0008 \\
\hline 29 & 7.14 & nd & nd & nd & 7.14 & 0.0001 & nd & nd & nd & 0.0002 \\
\hline 30 & 7.88 & 7.88 & nd & nd & 7.88 & 0.0009 & 0.0006 & nd & nd & 0.0014 \\
\hline 31 & nd & 8.30 & 8.30 & nd & 8.30 & nd & 0.0002 & 0.0002 & nd & 0.0002 \\
\hline 32 & nd & 8.55 & 8.55 & nd & 8.55 & nd & 0.0002 & 0.0002 & nd & 0.0003 \\
\hline 33 & nd & 8.64 & 8.64 & 8.64 & 8.64 & nd & 0.0003 & 0.0004 & 0.0003 & 0.0002 \\
\hline
\end{tabular}

Control: substrate with 20\% of apple pomace; 0h: control+MO70 before bioconversion; 24h: control+MO70 after 24h of bioconversion; 48h: control+MO70 after $48 \mathrm{~h}$ of bioconversion; $72 \mathrm{~h}$ : control+MO70 after $72 \mathrm{~h}$ of bioconversion and nd: not detected.

In the substrate without inoculation (control) 28 peaks were detected, distributed in the time 7.88 minutes of running. In the substrate that has been inoculated microorganisms of the strain 70 it was observed the formation of peaks initially (0h) and after 24, 48 and 72 hours, and noticed a total of 28, 26, 26 and 30 peaks respectively. Thus, it is observed that after 72 hours two new peaks appeared $(5,15)$, in times of 1.56 and 2.32 minutes, but with small areas $(0.001$ and 0.0002 , respectively). But this lack of the detection of other substances may have been produced by a limitation of the extraction method (liquid-liquid), the SPME (solid phase microextraction) extraction method may be tested in future work, as well as the passage of samples in a gas chromatography system and the spectrum of masses (GC-MS) for better identification and understanding of the nature of the compounds produced.

Observing the areas of all peaks detected, only five had relatively large areas (peak 2, 3, 6, 12 and 22). Figure 1 show all the superimposed chromatograms and that the peaks coincide in all analysis during the $0 / 24 / 48$ and $72 \mathrm{~h}$ of bioconversion. 
Figure 1 - Chromatographic profile of the volatiles compounds extracted after 72 hours of bioconversion of the apple pomace for microorganisms of the strain 70

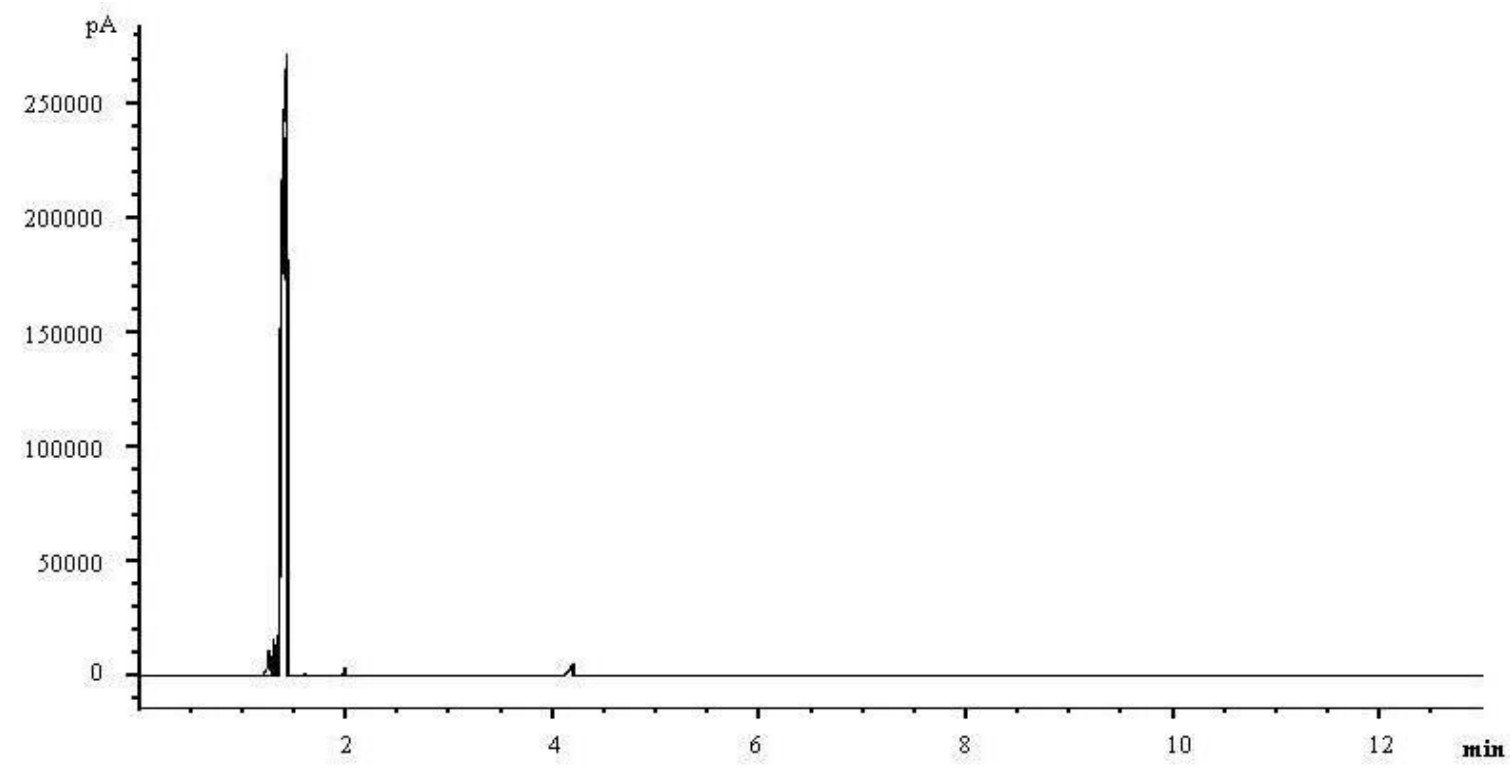

Once the force of the Brazilian economy comes from the large volume of agricultural commodities produced, a large amount of waste is also generated. Thus, it is necessary the improvement of alternatives for reuse, because the simple discard in the environment can cause serious ambiental problems. One possible application of these wastes could be their use as a carbon source in bioprocess for obtaining chemicals and products of higher value, being recorded in this study a possible use for the apple pomace, without the need of nutritional supplementation and with potential for future studies.

\section{Conclusion}

The apple pomace has potential as a possible component to the culture medium aiming the production of aromatic fruity compounds, without needing of nutritional supplementation. The proportion more appropriate for a liquid substrate is with $20 \%$ apple pomace for all strain of the microorganisms tested.

Only 70 and 74 strains produced fruit aroma (banana).

\section{Resumo}

Sabe-se que o bagaço de maçã é um subproduto sem valor econômico, o qual contém elevado teor de umidade, fibras e sólidos solúveis, dos quais grande parte são glicose, frutose e sacarose. Com esta composição, este é um meio potencial para o crescimento de microrganismos, sem necessitar da adição de nutrientes. Deste modo, o objetivo foi promover a bioconversão do bagaço de maçã (Malus domestica cv Fuji) por microrganismos pectinolíticos visando a produção de compostos aromáticos, para isso foram utilizadas 4 linhagens $(70,73,74$ e 144) e como substrato testadas proporções de bagaço de maçã úmido 5, 10, 20 e 30\% $\left(\mathrm{p} \mathrm{v}^{-1}\right)$ para uma fermentação em estado líquido por 72 horas. Observou-se um rendimento de $21,1 \pm 2,43 \%$ de bagaço e 78,9 $\pm 2,43 \%$ de suco, sendo que o bagaço apresentou 
grande quantidade de água (76,5 $\pm 5,39 \%)$. Dentre as proporções testadas a mais adequada foi $20 \%$ de bagaço de maçã úmido. Todas as linhagens cresceram no meio e conforme a análise sensorial apenas as linhagens 70 e 74 produziram aromas frutais, descrito como aroma de banana. Este é o primeiro estudo a reportar o potencial do bagaço de maçã como uma ferramenta para bioconversão visando à produção de aromas frutais sem haver a necessidade de grandes complementações nutricionais.

Palavras-chave: Malus domestica, bioconversão, resíduo agroindustrial, aroma frutal.

\section{References}

AACC - American Association of Cereal Chemists. Approved Methods of the American Association of Cereal Chemists. Saint Paul: American Association of Cereal Chemists Approved Methods Committee, 1995.

BRAMORSKI, A.; SOCCOL, C. R.; CHRISTEN, P.; REVAH, S. Fruity aroma production by Ceratocystis fimbriata in solid cultures from agro-industrial wastes. Revista de Microbiologia, São Paulo, v. 29, n. 3, p. 208-212, 1998. http://dx.doi.org/10.1590/S0001-37141998000300012

CARVAlHO, D. S.; MOLINA, G.; MARÓSTICA JUNIOR, M. R.; PASTORE, G. M. Fruity aroma production by Neurospora sitophila using green coffee beans as an alternative culture media. International Research Journal of Microbiology, Sapele, v. 3, n. 12, p. 388-392, 2012.

CHIAPPINI, C. C. J. Aromas naturais produzidos por microrganismos. Available in: <http://www.comciencia.br/comciencia/section\&edicao=28\&id=325>. Accessed: 10 out. 2010.

CHEN, H.; RUBENTHALER, G. L.; SCHANUS, E. G. Effect of apple fiber and cellulose on the physical properties of wheat flour. Journal of Food Science, v. 53, n. 1, p. 304-305, 1988. http://dx.doi.org/10.1111/j.13652621.1988.tb10242.x

DE MELlO, L. M. R. Circular Técnica no 64 - Produção e mercado da maçã brasileira Panorama 2005, disponível em: <http://www.cnpuv.embrapa.br/publica/circular/cir064.pdf〉. Acesso em 18 de ago. 2011.

DOWNING, D. L. Processed apple product. New York: Van Nostrand Reinhold, 1989.

DRUZIAN, J. I.; PAGLIARINI, A. P. Produção de goma xantana por fermentação do resíduo de suco de maçã. Ciência e Tecnologia de Alimentos, v. 27, n. 1, p. 26-31, 2007. http://dx.doi.org/10.1590/S0101-20612007000100005

FAO - Food and Agriculture Organization. Faostat, disponível em: 〈http://faostat.fao.org/site/339/default.aspx>. Acesso em: 18 de ago. 2011.

GULLÓN, B.; YÁNEZ, R.; ALONSO, J. L.; PARAIÓ, J. C. L-lactic acid production from apple pomace by sequential hydrolysis and fermentation. Bioresource Technology, v. 99, n. 2, p. 309-319, 2008. http://dx.doi.org/10.1016/j.biortech.2006.12.018

HANG, Y. D.; WOODAMS, E. E. Production of fungal polygalacturonase from apple pomace. LebensmittelWissenschaft und-Technologie/FST, v. 27, n. 2, p. 194-196, 1994.

KENNEDY, M.; LIST, D.; LU, Y.; FOO, L. Y.; NEWMAN, R. H.; SIMS, I. M.; BAIN, P. J. S.; HAMILTON, B.; FENTON, G. Apple pomace and products derived from apple pomace: uses, composition and analysis. In: LINSKENS, H. F.; JACKSON, J. F. Modern methods of plant analyses. Analysis of plant waste materials. Berlin: Springer Verlag, 1999. p. 75-119.

LUCHI, V.L. Botânica e fisiologia. In: EPAGRI. A cultura da macieira. Florianópolis: EPAGRI, 2002. p.743-745.

PETRI, J. L.; LEITE, G. B. Macieira. Revista Brasileira de Fruticultura. v. 30, n. 4, p.857-1166, 2008. http://dx.doi.org/10.1590/S0100-29452008000400001

RAUPP, D. S.; CARRIJO, K. C. R.; COSTA, L. L. F.; MENDES, S. D. C.; BANZATTO, D. A. Propriedades funcionais-digestivas e nutricionais de polpa-refinada de maçã. Scientia Agricola. v.57, n 3, p.395-402, 2000. http://dx.doi.org/10.1590/S0103-90162000000300004 
STREDANSKI, M.; CONTI, E.; STREDANSKA, S.; ZANETTI, F. $\gamma$-linolenic acid production with Thamnidium elegans by solid-state fermentation on apple pomace. Bioresource Technology, v. 73, n. 1, p. 41-45, 2000. http://dx.doi.org/10.1016/S0960-8524(99)00132-7;

UENOJO, M.; PASTORE, G.M. Isolamento e seleção de microrganismos pectinolíticos a partir de resíduos provenientes de agroindústrias para produção de aromas frutais. Ciência e Tecnologia de Alimentos, v. 26, n. 3, p. 509-515, 2006. http://dx.doi.org/10.1590/S0101-20612006000300004

VILLAS BÔAS, S. G; ESPOSITO, E. Bioconversão do bagaço de maçã: enriquecimento nutricional utilizando fungos para produção de um alimento alternativo de alto valor agregado Biotecnologia. Ciência \& Desenvolvimento, v. 14, p. 38-42, 2000.

Submetido em 02 mai 2012, Aceito para publicação em 20 mai. 2013. 